\title{
Post-foundational political thought: Political difference in Nancy, Lefort, Badiou and Laclau
}

\author{
Oliver Marchart \\ Edinburgh University Press, Edinburgh, 2007, vii + 198pp., \\ ISBN: 9780748624980
}

Contemporary Political Theory (2009) 8, 113-115. doi:10.1057/cpt.2008.36

References to 'the political' abound in contemporary political theory, especially of the Continental variety. Some draw this distinction from Carl Schmitt, others from Hannah Arendt, but few really dwell for long on what it means and what its wider implications might be for how we understand politics. Indeed, reference to the political in contrast to 'mere politics' can often seem a condescending snub to those preoccupied with the minutiae of party competition, policy choice or normative evaluation. The term 'political' is irreducible to such matters which, often rightly, are dismissed for their narrow preoccupation with (and legitimation of) the polity and its conventions, as opposed to the more profound question of how polities and conventions come to be instituted as they are. But such dismissal can also fail to set out what is at stake in drawing this distinction and how politics might be drawn back into the realm of the political.

In his dense but refreshingly instructive book, Oliver Marchart takes up directly the question of 'political difference' (the difference between the political and politics) and surveys a range of alternative stances on its meaning by some of the key contemporary political philosophers. This is a philosophical narrative restricted to assessing what others have to say on the topic and demonstrating recurring themes. But Marchart fruitfully illuminates the political difference and clarifies the overlaps and variations among what he designates 'post-foundational' political thought.

By post-foundational, Marchart understands a strand of thinking that emerges in the wake of Heidegger's critique of metaphysics. More precisely, Marchart is interested in a left-wing variant, which emphasizes the emancipatory possibilities of Heidegger's substitution of rational foundations for the notion of an 'Abyssal Ground' to Being. If no principle serves to found all existence, then the difference between specific beings and Being as such known as the 'ontological difference' - is insurmountable. 'Ontic', or historically and culturally determined, beings relate to Being as an open-ended range of possibilities rather than as a reflection of their innate features. Being forever exceeds the choices we make as beings and reveals to us the inescapable contingency of existence, which is why, according to Heidegger, we often go to great lengths to 'forget' it. 
To have no absolute foundation, however, is not to have any foundation at all. An Abyssal Ground is still a ground, Marchart reminds us, but one marked by its very absence or withdrawal. This is why we are dealing here with 'post' rather than 'anti' foundationalism. Human history is littered with foundational designs to fill this absence (God, Nature, Reason, and so on) and yet, inevitably, these expose themselves as limited and partial, futile if stubborn in their refusal of other ways of being. And here the political difference comes into its own as a tool of critical analysis. For Marchart, the political difference mirrors Heidegger's ontological difference. Where politics concerns strategy and the conventions of the contest for power, the political denotes the instituting moment in which the non-foundation discloses itself. That is, it is the moment(s) at which the terms and conditions of contest are disclosed as premised on a fundamental freedom, unconstrained by convention or strategy. This is not a moment of subjective choice but a 'leap of faith', an aporetic experience of decision where there are no rules. It is a moment that comes increasingly to the fore in Modernity as ontological foundations give way to an awareness of contingency. And it is to this very contingency that postfoundational thinkers appeal in their invocation of the political, sometimes (like Arendt) with an 'associational' quality and sometimes (like Schmitt) with a dis-associational or conflictual quality. In both, however, the political is an irreducible moment of radical freedom in which the collective is brought into existence through a founding 'event'. The political is therefore contrasted with tendencies that reduce it to something ontic ('the social' for Arendt, or liberal proceduralism for Schmitt). To invoke the political, then, is, invariably, to seek to divest politics of these neutralizing efforts and return it to an experience of public self-constitution, or of conflict and antagonism.

If Marchart identifies a common constellation of philosophical concerns, his survey of thinkers nevertheless reveals wide divergences in how the political is conceived. For Nancy - alongside the late Phillipe Lacoue-Labarthe - the political is disclosed in its very retreat from 'technological' societies, where alterity is increasingly denied. Nancy's later works on community, finitude and on freedom also draw out the political moment in these concepts, conceived in terms of plurality. Claude Lefort is well-known for his notion of the political as the 'empty place' of power and here Marchart fills out this phrase, emphasizing Lefort's ability to link political difference to social institutions. More than Nancy, Lefort underscored the presence of institutionalized conflict as an externalization of the absent ground. Badiou, on the other hand, comes closest to reinstating a kind of foundationalism in his neo-Platonic philosophy. Inverting the polarity of political difference, for Badiou it is politics that interrupts the political: an 'unnameable' event that explodes the ontical order, signifying an unbridgeable gap between the two. Laclau, on the other hand, constructs a more mediated articulation between politics and the political. 
'Hegemonic' discourses and discursive practices are 'sediments' whose contingency is permanently open to dislocation and political 'reactivation', paving the way for new hegemonic practices.

If he holds rather cautiously to a philosophical quest at definition and clarification, Marchart has nevertheless done an invaluable job in drawing out the similarities and differences between these key thinkers and exploring their common point of reference in what, in his final chapter, he defines as 'political ontology'. But it remains that each thinker has a different take on how political ontology is to be articulated with concrete politics, if at all. Sometimes the effort to define the political comes at the cost of a heavily philosophical or ethical notion of radical politics. Perhaps this is not surprising when we are dealing with an 'absence' whose paradoxical presence can be figured in a myriad of ways. It is hard to avoid the view - and it pops up in Marchart's text from time to time - that there is something semi-religious about the notion of an absent ground. Indeed, as a marker of contingency, there is a strong resemblance between the 'onto-political' and aspects of religious experience: the political is 'everywhere', suggests Marchart, but this is a place 'nobody has ever seen' (p. 174). It is no surprise, further, that each of the surveyed thinkers has drawn upon elements of theology to develop their claims. This provokes the question as whether it is exclusively in conventional politics that we might detect the political and not, rather, in the practices of faith, commitment and religion?

Marchart has done a fine job in exploring and clarifying what has become a buzzword in radical theoretical discourse. This is a book that deserves to be read by all those who wish politics could be just that bit more political.

James Martin

Goldsmiths, University of London, UK

\title{
Ecological politics and democratic theory: The challenge to the deliberative ideal
}

\author{
Mathew Humphrey \\ Routledge, London, 2006, 169pp., ISBN: 100415314313
}

Contemporary Political Theory (2009) 8, 115-121. doi:10.1057/cpt.2008.35

Mathew Humphrey has written an extremely interesting book offering a distinctly novel take on the relationship between green politics and environmental issues and democratic theory. In the prelims one of the questions 